\title{
Daqing Crude Oil Price Forecast Based on the ARIMA Model
}

Open Access

\author{
Li Quan*
}

Department of Economics and Management, North China Electric Power University, Baoding, Hebei, 071000, P.R. China

\begin{abstract}
Oil is the lifeblood of the industrial economy, oil prices are affected by many factors. China is a major industrial country, changes in the price of oil will affect many aspects of economic development, and therefore the price of crude oil research is extremely important. In this paper, monthly average prices of crude oil in Daqing from January 2000 to December 2010 are utilized to do the research. Based on ARIMA model by building software using EVIEWS, rule of oil price movements is found and a prediction of oil price is made using the data from the first 10 months of 2011.
\end{abstract}

Keywords: ARIMA model, Crude oil prices, forecast.

\section{INTRODUCTION}

The oil, as industrial production of raw material, has a pivotal role in the rapid economic development. As a major industrial country, China's demand for oil has leapt to the world. Faced with huge demand, relying solely on its own is not enough mined, and the source of China's oil is nothing more than the exploitation of domestic and foreign imports. As international oil demand and supply complex, the price of oil is also erratic, which makes China's domestic oil prices there are some changes. Daqing Petroleum base is the most important oil producer, analyzing the price of crude oil for China's economy is significant.

Oil price forecast from the era after the occurrence of the two oil crises, governments began to pay attention to it. There are about more than 600 institutions specializing in oil price forecasts. Forecasting methods they used can be roughly divided into two categories, qualitative and quantitative forecasting methods to predict. On behalf of the former is Delphi method, it basically can be divided into three structural models such as regression, linear and nonlinear time series time series model under the terms of the prediction after different quantitative models used. Factor structure model can well explain the effects of changes in supply and demand, but Pindyck (1999) [1] found that it predicted the effect on the price of oil is not very good. The time series models, especially linear time series models, such as the ARIMA method can be used to predict oil prices. Because it is predictable process, not only to consider the value of the predicted change in the past and the current period value, while the value of the fitting error model generated in the past but also as an important factor into the model, which will help improve the accuracy of the model.

In the oil price forecast, given in the prediction method of choice is important. However, due to changes in the international crude oil price is affected by many factors. Such as

*Address correspondence to this author at the Department of Economics and Management, North China Electric Power University, Baoding, Hebei, 071000, P.R. China; Tel: +8613020806889 ;

E-mail: 13020806889@163.com market supply and demand conditions, development of the situation in the world economy, even terrorism, geopolitical risk, speculation, weather changes and other uncertain factors also affect changes in international oil prices.

In 2014, as the US quantitative easing monetary policy further reduce or even completely stopped, it will allow the oil injection channel speculative funds continued gradual depletion of oil speculators wildest speculation in oil era is gradually leave. When the integrity of the major banks to exit the oil market, it will completely change has lasted more than a decade of the "Wall Street refiners" dominant oil situation.

\section{LITERATURE REVIEW}

Before the 1970s, the era of cheap oil is due to the longterm stability of oil prices and oil price volatility, few people concerned, and after the two oil crises from the 1970s, governments began to pay attention to oil prices.

Pioneer of the study of oil prices is Hotelling (1931) [2] which is famous exhaustible resource model. Hotelling using this model discussed exhaustible resources, but the oil prices is most intense in many of exhaustible resources to fluctuations, and therefore it is most interesting. He put resources as an asset buried in the ground, and how the goal is to find an optimal pricing method allows maximum NPV.

Conclusion of this model is the resource price increase rate equal to the discounted value, which means that if the owner of the resource exploitation of resources is lower than the growth rate of capital gains resulting interest rate, he would tend to put resources buried in the ground; If higher interest rates, the bias in mining, in order to get a higher NPV.

Along Hotelling research ideas, many papers later by setting the oil market behavior of different structures and different actors involved in the oil market, the establishment of all kinds of theoretical models, the introduction of various parameters to analyze the causes of oil price volatility and future trends, such as Pindyck (1978) [3]; Gately (1983) [4]; 
To explain and predict changes in crude oil prices firstly need to understand the behavior of crude oil prices itself (Michael (2009) [5]; Kendix (2010) [6]; Leder (2008) [7]). Jose (2002) [8] analysis results on the price of crude oil using Hurst multidimensional showed that the crude oil market is a highly complex process of interaction at different time scale, long-term memory mechanism to influence the evolution of oil prices. Burlaka, V. G.,Sherstyxik, R. V(2008) [9] usding of competitive market behavior study dynamical behavior of crude oil prices, and found the existence of even a stable oil market equilibrium price.

In addition to the study of the structure of the oil market, you can retrieve the oil futures market to study literature as oil financial enhancements. Abosedra, S. and Baghestani, H. (2004) [10] indicates that the price of crude oil futures month short-term prediction of future oil prices have a significant indication. There are study discussing the relationship between the effectiveness of the crude oil futures market prices and other economic variables using cointegration theory. Such Crowder and Hamed (1993) [11] use cointegration testing effectiveness and crude oil futures arbitrage condition market and Gulen (1998) [12] use WTI crude oil futures contract in the main price and the spot price of econometric analysis. It found that not all scholars are inclined to the importance of oil futures, as well as some scholars believe that the impact of oil prices on the oil futures market is zero, represents Moosa and Alloughani (2001) [13] collected WTI spot prices and futures prices monthly closing price data.

Some studies focus on oil prices and other factors literature analysis, such as social and political events, strategic inventory changes, economic growth, natural factors, changes in exchange rates, the market impact of oil price speculation on the impact of predictive analytics. (Chaudhuri K (2001) [14]; Smith, Grimm (2003) [15]; Michael Ye, John Zyren, Carol Joyce Blumberg, Joanne Shore (2009) [16]; Watkins, G.C. and Plourde (1994) [17]).

Day compared the volatility of crude oil since November 2003 to March 2006 in the fitted GARCH $(1,1)$ and EGARCH $(1,1)$ model, using the least squares method to estimate the parameters and make predictions [18].The results show that GARCH / EGARCH model estimated volatility parameters are in line with the volatility of volatility data for information response. However, with the implied volatility and GARCH model to estimate the parameters of the integrated volatility might get better prediction results.

Duffie developed to predict since crude oil from May 2005 to July 2008, the internal energy, and the yield based on the natural gas market volatility and sample-sample [19]. They found in the sample or sample forecasting, predicting the effect of implied volatility are the best, but in the majority of sample predictions example, GARCH model provides a forecast based on historical volatility as good prediction.

Zhang Yuejun [20] grain China Daqing Petroleum based data is established based on GARCH generalized error distribution (GED) of $(1,1)$, GARCH-M $(1,1)$ and TGARCH $(1,1)$ distribution and empirical analysis showed that China's oil price significant fluctuations of $\mathrm{ARCH}$ effect, but with different international markets, volatility of short half-life, for five days. Fluctuations in the price of oil by China is not entirely determined by the oil market itself, there is also the impact of other external factors, but little impact such external factors, is about $8 \%$, empirical also show that the distribution ratio GED based on the normal distribution model fit better than GARCH.

\section{FACTORS AFFECTING OIL PRICES}

As a non-renewable petroleum resources, the main factors affecting price including the unexpected geopolitical events, changes in stocks, the dollar exchange rate fluctuations, speculation and psychological expectations and OPEC's oil strategy.

\subsection{Geopolitical Events}

The so-called political factors affecting changes in oil prices, means that sudden political events, such as the outbreak of war, mutiny, riot, revolution, coup, as well as to achieve some kind of political and economic purposes action taken. On the whole, political reasons are some of the main factors affecting the fluctuation in oil prices, or even directly, the only significant cause of short term ups and downs of oil prices.

After $9 / 11$ in United States, a short crude oil prices soared in the atmosphere of panic, Brent crude was up \$ 31.1 per barrel. In January, due to the smooth progress of the US war in Iraq, oil prices stop rising rapidly decline, the average price of OPEC crude oil fell below \$ 18 a barrel. Iraq's oil production stagnated because of the $3^{\text {rd }}$ Gulf War in early 2003; political instability in Venezuela and the nationwide strike severely affected oil production, exports, and the direct impact of the international oil market. Implementation of the Russian oil and gas industry nationalization policy, increasing the energy pattern of instability in East Asia and the Asia-Pacific region, these factors led to the volatility of oil prices.

The situation in the Middle East continued turmoil in major oil producers, as well as frequent terrorist activities that may cause damage to oil production facilities can ensure that the global market for crude oil supply concerns, making it possible to form a so-called terror premium in the international market, and through speculation further enlarge. This makes the oil supply cost increase, which is the most direct cause of recent fluctuations in world oil prices.

Geopolitical events occur will be generated by short-term supply and demand on the international market, but its influence is short, after short time of adjustment, its impact will continue to weaken until it disappears.

\subsection{Changes in Oil Supply and Demand Situation}

Strategic oil reserves and inventory in the international oil market directly related to the change in the number of changes in the world oil market supply and demand balance.

On the one hand, oil stock on oil supply and demand gap has a direct regulatory role, which is able to iron out shortterm fluctuations in oil prices by selecting its reorientation. On the other hand, stock market supply and demand is a reflection of the level of tension. 
Crude oil prices are also affected by the Energy Information Administration (EIA) of crude oil inventories (COI) report. EIA is a Department of Energy (DOE) branch, COI report released every Wednesday 10:30 AM EST. Like other economic reports, before the report was released, traders rely on consistent inventory estimates and expectations. If the COI report with a far cry from the expected inventory levels, crude oil and energy markets will react strongly. When stocks fall below expectations, the energy markets tend to grow when the stock rises, and more than the market consensus estimate, the energy market tends to decline. "Increase" refers to rising of inventory, "down" refers to the inventory reduction. Because this is a snapshot of one week, any effects are usually short-lived.

Recently, in the ninth G20 summit held in Australia, China announced that it would release oil inventory data on a regular basis. From the international market, China announced oil inventories, will give traders the futures market is a very important trading guidelines alone speak from the perspective of inventory, traders focused on the United States before, this is because the Chinese were not disclosed, this data will be released soon attracted the attention of major traders.

\subsection{Dollar}

Because world oil prices were denominated in US dollars, the dollar value will lead oil producers to raise prices of its exports of petroleum products, coupled with the investment behavior of the oil futures market and people's psychological expectations, short-term fluctuations in oil prices more intense.

Factors affecting the dollar exchange rate are mainly the following two: On the one hand, instability in the Middle East will affect the stability of the oil supply, and more importantly, it will seriously affect people's psychological expectations, will indirectly affect the US economy, further affecting the dollar. On the other hand, US interest rates the Fed's next adjustment confusing, unstable financial markets in the United States so may result in volatility and sharp depreciation of the dollar.

Theoretically, when the dollar index weakened dollardenominated crude oil prices from the perspective of the euro or the yen, it becomes cheaper, the demand will rise; on the contrary, when the US dollar, euro or yen-denominated crude oil price your side, demand for crude oil will drop. International crude oil transactions are denominated in US dollars, while consumer countries with their own currencies to buy crude oil products. Production of crude oil sales made abroad dollars, and buy goods and services from another country with the world's other currencies. For OPEC member countries concerned, this situation is more serious, the dollar impact varies greatly between countries. International crude oil companies sell their oil in dollars of products, with the local currency to pay wages, benefits, taxes and other fees. When the dollar, the US dollar relative to the country can buy cheap oil, while the state and can not be pegged to the dollar to benefit from crude oil imports.

\subsection{Speculation, Psychological Expectations}

Oil price formation on the world oil market system throughout the entire world oil market system from the spot and future's markets, which constitute the spot market price of oil is formed by the oil futures market. In order to chase profits, Arbitrage activity of futures speculators in the oil futures market is frequent, and their speculation led to volatility in oil prices.

Coupled with the expected behavior of the psychological impact on people, the use of market information in the futures speculators continue to hype selling point, and further increase the volatility of oil prices. For example, with oil prices soaring, people are expected to further rise in oil prices, in such expectations, speculators in the futures market has been buying oil futures. Expected itself is like having a self-fulfilling prophecy function, leading to a further rise in oil prices the fact that "speculators then took the opportunity to sell at a higher price, which earned high post.

\section{VARIABLES AND EQUATIONS}

Daqing oil field is the largest oil field of 26 September 1959 found the world's top ten oil fields, located in China's Daqing City, Heilongjiang Province, into the development and construction in 1960. As China's largest oilfield of Daqing oil production base in 50 years, the production of crude oil accounts for more than 40 percent of China's onshore crude oil production in the same period. Crude Oil prices and international oil prices and the associated degree of macroeconomic Daqing, Daqing crude oil price trend for the future to predict, is of great significance. Daqing price trends and international crude oil price is entirely consistent Daqing, both of the past 10 years the price has remained slow rise

Daqing Petroleum base is the most important oil producer, to analyze the price of crude oil for China's economy is significant. To this end, we have found from January 2000 to December 2010 the average monthly price of Daqing crude data.

\subsection{Stationary Test}

The establishment of data in January 2000 to December 2010 of the average monthly price of Daqing crude oil in the timing diagram is shown in Fig. (1).

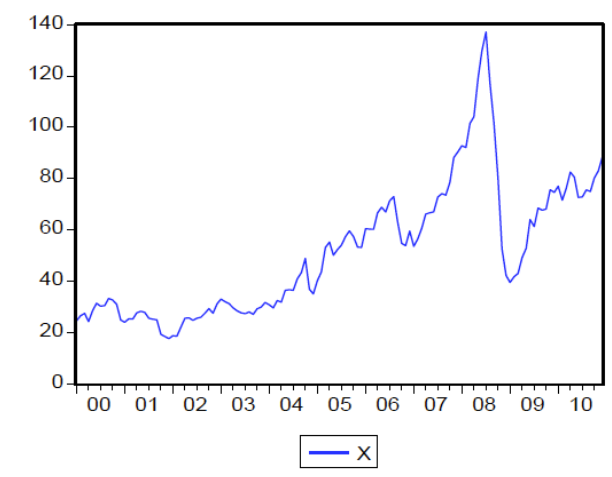

Fig. (1). The series of daqing crude oil price.

As can be seen from the graph of the sequence exponential rise, can initially determine the time-series data significantly non-stationary. We calculate raw data AC (autocorrelation coefficient) and PAC (partial autocorrelation coefficient). The results are shown in Table $\mathbf{1}$ : 
Table 1. AC (autocorrelation coefficient) and PAC (Partial autocorrelation) data.

Sample: 2000M01 2010M12 Included observations: 132

\begin{tabular}{|c|c|c|c|c|c|c|c|c|}
\hline \multicolumn{2}{|c|}{ Autocorrelation } & \multicolumn{3}{|c|}{ Partial Correlation } & \multirow{2}{*}{$\frac{A C}{0.950}$} & \multirow{2}{*}{$\begin{array}{l}\text { PAC } \\
0.950\end{array}$} & \multirow{2}{*}{$\frac{\text { Q-Stat }}{121.83}$} & \multirow{2}{*}{$\begin{array}{l}\text { Prob } \\
0.000\end{array}$} \\
\hline 1 & & 1 & & 1 & & & & \\
\hline & 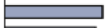 & 5 & 1 & 2 & 0.886 & -0.161 & 228.75 & 0.000 \\
\hline & 品 & 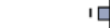 & 1 & 3 & 0.815 & -0.103 & 319.78 & 0.000 \\
\hline 1 & 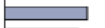 & 15 & 1 & 4 & 0.740 & -0.059 & 395.35 & 0.000 \\
\hline & 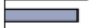 & $1]$ & 1 & 5 & 0.667 & -0.004 & 457.28 & 0.000 \\
\hline 1 & 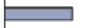 & 1 & 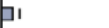 & 6 & 0.609 & 0.106 & 509.27 & 0.000 \\
\hline & 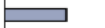 & 1 & 11 & 7 & 0.562 & 0.048 & 553.90 & 0.000 \\
\hline 1 & ב & 1 & 1 & 8 & 0.524 & 0.021 & 593.04 & 0.000 \\
\hline 1 & $\square$ & 1 & 11 & 9 & 0.496 & 0.042 & 628.46 & 0.000 \\
\hline 1 & $\Longrightarrow$ & 1 & 1 & 10 & 0.461 & 0.080 & 662.03 & 0.000 \\
\hline 1 & $\square$ & 1 & P & 11 & 0.476 & 0.075 & 695.18 & 0.000 \\
\hline 1 & 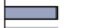 & 1 & 1 & 12 & 0.471 & -0.028 & 727.88 & 0.000 \\
\hline 1 & $\square$ & 1 & 1 & 13 & 0.466 & 0.001 & 760.19 & 0.000 \\
\hline 1 & $\square$ & $\square$ & 1 & 14 & 0.441 & -0.202 & 789.38 & 0.000 \\
\hline 1 & 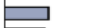 & 1 & 1 & 15 & 0.407 & -0.031 & 814.47 & 0.000 \\
\hline 1 & 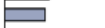 & $1]$ & p & 16 & 0.372 & 0.047 & 835.58 & 0.000 \\
\hline 1 & ש & 1 & ק & 17 & 0.347 & 0.144 & 854.09 & 0.000 \\
\hline 1 & 巨 & 1 & 5i & 18 & 0.331 & 0.092 & 871.12 & 0.000 \\
\hline 1 & 曰 & 15 & 1 & 19 & 0.317 & -0.061 & 886.88 & 0.000 \\
\hline 1 & 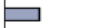 & 1 & 11 & 20 & 0.311 & 0.025 & 902.18 & 0.000 \\
\hline 1 & 曰 & 1 & 1 & 21 & 0.311 & 0.024 & 917.58 & 0.000 \\
\hline 1 & 口 & 1 & 1 & 22 & 0.311 & 0.002 & 933.13 & 0.000 \\
\hline 1 & $\Xi$ & 15 & 1 & 23 & 0.305 & -0.078 & 946.27 & 0.000 \\
\hline 1 & $\square$ & 吅 & 1 & 24 & 0.293 & -0.116 & 962.32 & 0.000 \\
\hline 1 & $\boxminus$ & 1 & 1 & 25 & 0.278 & 0.012 & 975.09 & 0.000 \\
\hline 1 & $\boxminus$ & 1 & 1 & 26 & 0.257 & -0.001 & 986.12 & 0.000 \\
\hline 1 & $\square$ & 1 & 1 & 27 & 0.225 & -0.021 & 994.66 & 0.000 \\
\hline 1 & 曰 & 1 & 1 & 26 & 0.193 & 0.028 & 1001.0 & 0.000 \\
\hline 1 & 巨 & 1 & 1 & 29 & 0.164 & 0.021 & 1005.6 & 0.000 \\
\hline 1 & ים r r la & 15 & 1 & 30 & 0.137 & -0.044 & 1008.8 & 0.000 \\
\hline 1 & ים l l & $1]$ & י & 31 & 0.124 & 0.062 & 1011.5 & 0.000 \\
\hline 1 & ון & 口 & 1 & 32 & 0.101 & -0.188 & 1013.3 & 0.000 \\
\hline 1 & יבן & 1 & 1 & 33 & 0.083 & -0.000 & 1014.6 & 0.000 \\
\hline 1 & ין & 1 & I & 34 & 0.070 & 0.013 & 1015.4 & 0.000 \\
\hline 1 & 1 & 1 & 1 & 35 & 0.053 & -0.068 & 1015.9 & 0.000 \\
\hline 1 & 1 & 1 & $\boxminus$ & 36 & 0.049 & 0.200 & 1016.4 & 0.000 \\
\hline
\end{tabular}

The test shows the sequential order difference is stationary, and its trailing AC performance, the performance of its PAC step censored. Which can determine a preliminary order difference sequence for AR (1) model.

\subsection{Equations Form}

From the first-order difference sequence of $\mathrm{AC}$ and $\mathrm{PAC}$ figure we initially determined that as AR (1) model, in this, the first difference model may wish to set the sequence of AR (1), AR (2), ARMA (1,1).

According to the result, we selected the first difference sequence AR (1) model. In order to determine the sequence of the first-order differential reliability AR (1) model, we need to be residual autocorrelation - partial autocorrelation of diagnostic tests.

From the autocorrelation and partial autocorrelation can be seen no longer exists residuals autocorrelation, indicating that the model fit well. Here we look at AR (1) model fitting results as shown Fig. (3).

\section{PREDICTIONS}

There are two ways of prediction model, one is a dynamic forecasting model, the other is static prediction model. Dynamic forecasting model is shown in Fig. (3).
Seeing from the results, AC decay to zero very slowly, so conclude non-stationary sequence $\mathrm{y}$. To further illustrate the raw data is non-stationary series.To further illustrate the raw data is non-stationary series, we test ADF.

From the result, we see that at the significance level of 0.01 , which accept the existence of a unit root null hypothesis, it can be concluded that this data is non-stationary time series data. Furthermore, in order to find out the order of the non-stationary, we were the first difference of the original data sequence ADF test. The results show a significant lower level of 0.05 was significantly reject the unit root null hypothesis, indicating that the first difference series is stationary, so you can determine ARIMA model $d=1$.

From the above analysis, we determined the ARIMA model, so just the raw data to make a difference order to obtain an order difference sequence can be analyzed. as Fig. (2).

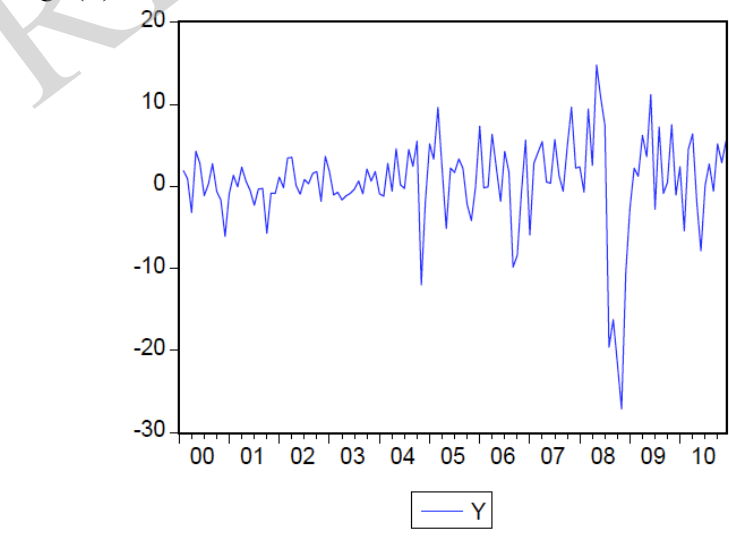

Fig. (2). Line charts of the first difference sequence.

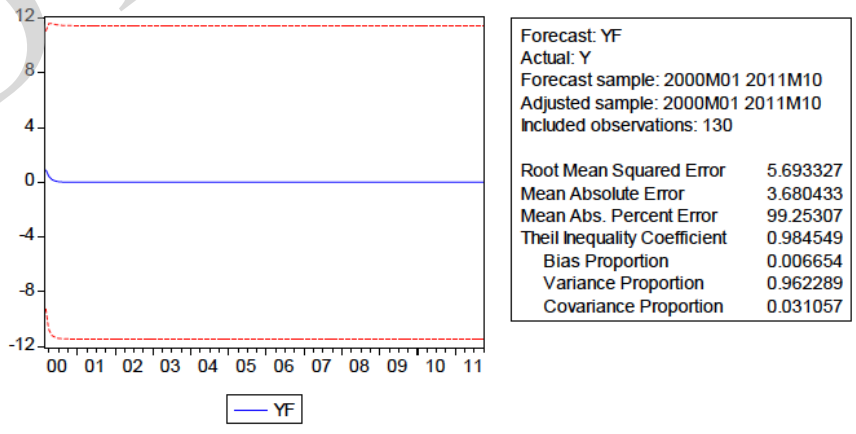

Fig. (3). Dynamic forecasting mode.

The solid line represents the predicted value of $y$, the two dashed lines are provided 2 times the standard deviation of the confidence interval. You can see that with the growth forecast time predictive value quickly tend to mean a sequence of (close to 0 ). The right of the chart is a list of criteria to evaluate predictions, such as the mean squared prediction error and the square root of (RMSE), Theil inequality coefficient and its decomposition.

We can see that Theil inequality coefficient is 0.984549 , indicating that the predictive power of the model is not very good, but it's a very small proportion of the decomposition indicate bias, a larger proportion of variance explained in greater volatility in the actual sequence, and the fluctuation of the simulation sequence small, this may be too long due to prediction.

Here we look at the effect of the model prediction, Fig. (4), seen from the graph of dynamic predictive value is al- 
most a straight line, indicating that the effect is very good dynamic prediction.

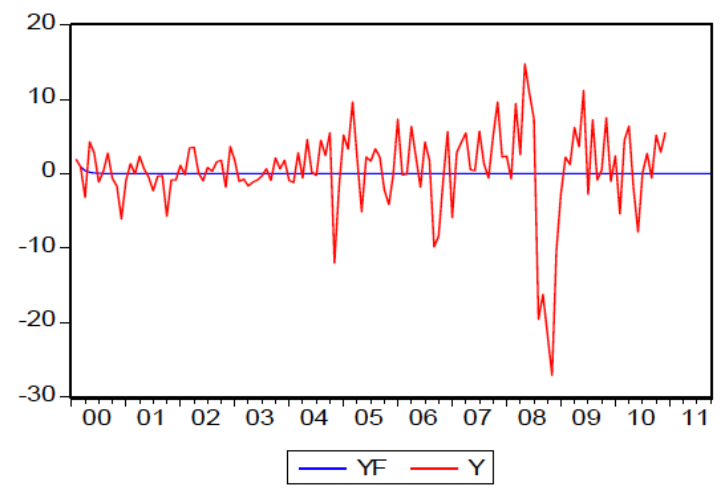

Fig. (4). The result of dynamic forecasting mode.

Let us look at the static prediction as Fig. (5).
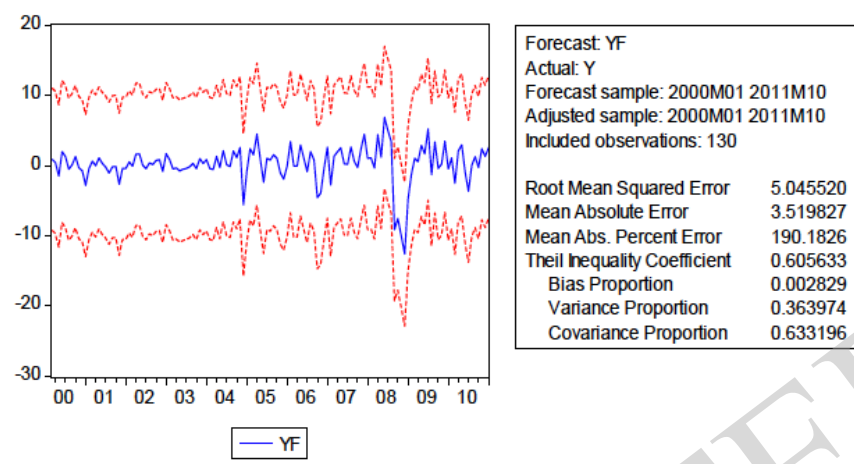

Fig. (5). Static forecasting mode.

As can be seen from the figure, the static prediction model is ideal. Look at predicting renderings as Fig. (6).

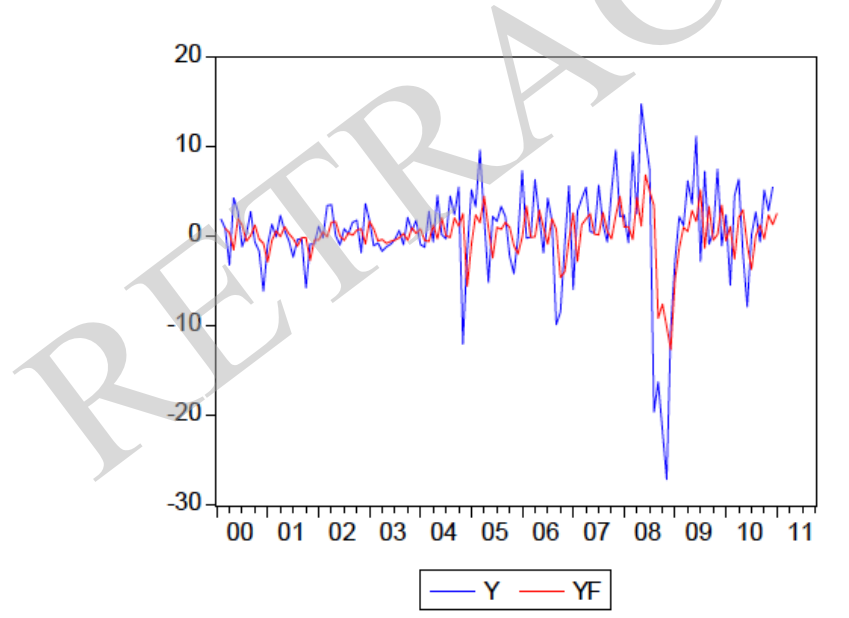

Fig. (6). Fitting static renderings.

As can be seen from the figure, the effect of static prediction model is quite good. Finally, we get an order difference sequence AR (1) model expression:

$$
y_{t}=0.460998 y_{t-1}+\varepsilon_{t}
$$

That

$$
(1-B) X_{t}=0.460998(1-B) X_{t-1}+\varepsilon_{t}
$$

Final prediction of 10-month average oil price in 2011 is shown in the following table.

\begin{tabular}{|c|c|c|c|c|c|}
\hline Month & $\mathbf{1}$ & $\mathbf{2}$ & $\mathbf{3}$ & $\mathbf{4}$ & $\mathbf{5}$ \\
\hline Price & 94.9 & 98.78 & 109.62 & 118.05 & 116.83 \\
\hline Month & 6 & 7 & 8 & 9 & 10 \\
\hline Price & 113.03 & 113.11 & 113.56 & 110.98 & 105.68 \\
\hline
\end{tabular}

\section{CONCLUSION}

Previous From a practical situation, factors that affect the price of oil is its complexity, changes in oil prices also appears to be no rules can be found. By ARIMA model to historical data based on the price of oil, leaving aside the mutation prediction factors is difficult to grasp, and after repeated identification and modification, and validation of historical data, until the ideal model, accurately grasp prices the shortterm changes in the law.

Because of a lot of factors that affect the price of oil, this paper considers only historical data, and the data taken is limited, so there may be some predictions errors. Of course, the model is not static over time, the new data series continue to appear, the relevant parameters of the model needs to be adjusted or re-fit model to improve prediction accuracy.

From the Daqing oil price forecasting, ARMA model is appropriate, the static model better simulated historical values. But this paper does not consider the impact of external factors, historical data selected time period is shorter.

\section{CONFLICT OF INTEREST}

The author confirms that this article content has no conflict of interest.

\section{ACKNOWLEDGEMENTS}

Declared none.

\section{REFERENCES}

[1] R. Pindyck, "The Long-Run Evolution of Energy Prices ",The Energy Journal, vol. 20, no. 2, 1999.

[2] H. Hotelling, "The economics of exhaustible Resources ". Journal of Political Economy, vol. 4, pp. 137-157, 1931.

[3] R.S. Pindyck, "Gains to producers from Cartelization of exhaustible resource", Reviews of Economics Statistics, vol. 2, pp. 238-251, 1978.

[4] D. Gately, "OPEC: retrospective and prospects 1972-1990", European Economic Review, vol. 21, pp. 313-331, 1983.

[5] M. Ye, J. Zyren, C.J. Blumberg, J. Shore, "A Short- Run Crude Oil Price Forecast Model with Ratchet Effect", Atlantic Economic Journal, vol. 3, 2009.

[6] M. Kendix, W.D. Walls, "Estimating the impact of refinery outages on petroleum product prices", Energy Economics, vol. 52, no. 6, pp. 1291-1298, 2010.

[7] F. Leder, J.N. Shapiro, "This time it's different - An inevitable decline in world petroleum production will keep oil product prices high, causing military conflicts and shifting wealth and power from democracies to authoritarian regimes", Energy Policy, vol. 3, no. 8, pp. 2850-2852, 2008. 
[8] J. Alvarez-Ramirez, M. Cisnerlsl. etc, "Multifractal Hurst analysis of crude oil prices." Physica A, vol. 313, pp. 651-670, 2002.

[9] V.G. Burlaka, R.V. Sherstyxik, "Petroleum products market formation in Ukraine under conditions of world petroleum prices increase", Actual Problems of Economics, vol. 85, pp. 16-23, 2008.

[10] S. Abosedra, and Baghestani, "On the predictive accuracy of crude oil future prices”, Energy Policy, vol. 32, pp. 1389-1393, 2004.

[11] Crowder and Hamed, "Oil Price-A Discussion Of Influnceing Issues", Energy Industry Research, February 25, 2003.

[12] Gulen, "Exhaustible resources and industrial structure: ANashCournot approach to the world oil market", Journal of Political Economy, vol. 84, pp. 1079-1093, 1998.

[13] Morana, "A semiparametric approach to short-term oil price forecasting", Energy Economics, vol. 23, pp. 325-338, 2001.

[14] Chaudhuri K, "Long-run Prices of Primary commodities and oil Prices”, Economics, vol. 33, pp. 531 -538, 2001.
[15] Smith, Grimm, "Gannon. Dynamic of Competitive Strategy B", New York: Wiley.

[16] Michael Ye, John Zyren, Carol Joyce Blumberg, Joanne Shore, "A Short-Run Crude Oil Price Forecast Model with Ratchet Effect", Atlantic Economic Journal.

[17] Watkins, G.C. and Plourde, "A. How volatile are crude oil prices?", OPEC Review, vol. 18, no. 4, pp. 220-245, 1994.

[18] Day, "On Estimating Conditional Heteroskedastic Models Using Empirical Likelihood Estimations ", International Journal of Intelligent Technologies and Applied Statistics, vol. 5, no. 2, pp. 201216, 2012.

[19] Duffie, "WTI crude oil price volatility GARCH Model Based", International Journal of Intelligent Technologies and Applied Statistics, vol. 5, no. 2, pp. 201-216, 2010.

[20] Y. Zhang, "Study based on Chinese crude oil price volatility GED $\sim$ GARCH model", Mathematical Statistics and Management, 2007.

Received: May 26, 2015

Revised: July 14, 2015

Accepted: August 10,2015

(C) Li Quan; Licensee Bentham Open.

This is an open access article licensed under the terms of the (https://creativecommons.org/licenses/by/4.0/legalcode), which permits unrestricted, noncommercial use, distribution and reproduction in any medium, provided the work is properly cited. 